\title{
Erratum: Occupational exposure to diesel engine exhaust and alterations in lymphocyte subsets
}

Lan Q, Vermeulen R, Dai Y, Ren D, Hu W, Duan H, Niu Y, Xu J, Fu W, Meliefste K, Zhou B, Yang J, Ye M, Jia X, Meng T, Bin P, Kim C, Bassig BA, Hosgood HD III, Silverman D, Zheng Y, Rothman N. Occupational exposure to diesel engine exhaust and alterations in lymphocyte subsets. Occup Environ Med 2015;72:354-59.

There are two corresponding authors for this paper as follows:

Qing Lan, Occupational \& Environmental Epidemiology Branch, Division of Cancer Epidemiology and Genetics, National Cancer Institute, NIH 9609 Medical Center Drive, Room 6E138, Rockville, Maryland 20850, USA; qingl@mail.nih.gov

Yuxin Zheng, National Institute of Occupational Health and Poison Control, China CDC No 29, Nanwei Road, Beijing, 100050, P. R. China; zhengyx@chinacdc.cn

Occup Environ Med 2016;73:804. doi:10.1136/oemed-2014-102556corr1

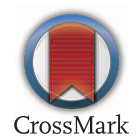

